\title{
Psaním k porozumění literatuře
}

\author{
Jitka Cholastová
}

\begin{abstract}
Understanding Literature through Writing

The paper deals with methods of creative writing in context of literary studies both in Czech and foreign (Anglo-Saxon) academic environment. Through a comparative analysis of various historically anchored approaches, it shows the possibilities of using these methods in the educational process. The very term „creative writing“ appears to be inaccurate in this context, and some authors replace it with their own terms (,textual intervention“, „transformative writing“, „literary experiment"). The aim of these methods is to understand literature. Writing becomes part of an interpretative dialogue.
\end{abstract}

\section{KEYWORDS}

Creative Writing; Literary Studies.

\section{KLÍčOVÁ SLOVA}

Tvưrčí psaní; literární vzdělávání.

Teze, že díky vlastnímu psaní se můžeme dobrat lepšího pochopení literárního díla, potažmo že existuje spojitost mezi schopností produkovat a recipovat texty, není sama o sobě nijak nová ani neobvyklá. Svým způsobem se o ni opírá veškerá literární kritika a interpretace; formulování hodnotových soudů, ale i artikulace významů má při psaní o literárním díle spíše povahu cyklického procesu, který se nevyčerpává ani odevzdáním verze pro tisk, než jednoznačného a definitivního aktu. Rozšířená - i když při bližším zkoumání nikoli neproblematická - je také představa, že spisovatel činný v oblasti beletrie má ty nejlepší předpoklady být také jejím pozorným a znalým čtenářem, kritikem, interpretem. 
Psaní odborně laděných metatextů má stálé místo také ve vzdělávání. Adept literárněvědné bohemistiky během studia připraví desítky referátů a seminárních prací. Požadavky na ně kladené bývají odvozeny od tradičních žánrů analytické interpretační studie, argumentační eseje, recenze či kritiky. Referáty realizované v seminářích slouží obvykle jako informační základna pro další společnou práci, seminární práce plní funkci „výstupní kontroly“ a jsou (mnohdy rozhodující) součástí evaluace. Naplňovat požadovaná kritéria odborných prací se studenti učí v seminářích typu úvod do studia, případně v samostatném kurzu akademického psaní. Pokud bohemistické pracoviště nabízí také seminář tvưrčího psaní, bývá vnímán jako doplňková, spíše zájmová aktivita, rozvíjející individuální styl pisatelů a př́ipadně i jejich literární talent.

Může mít pro studium literatury význam také jiné než odborné psaní, tedy například i vlastní psaní literární? Může být textotvorná aktivita studentů součástí samotného procesu učení, nikoli jen jeho úvodem či završením? A může mít vedle odborného či literárního (v praxi často spíše kvazi-odborného a kvazi-literárního) psaní tato práce se slovy ještě i zcela jinou podobu? Naše zkoumání těchto otázek se přirozeně člení do dvou hlavních částí. První postihuje hlavní vývojové obrysy dané oblasti a opírá se zčásti o aktuální syntézy badatelů ukotvených v angloamerickém kontextu. ${ }^{1}$ Druhá se zaměřuje na analýzu současných publikací usilujících propojit literárněvědné vzdělávání s vlastním psaním a nabízejících zpravidla vedle teoretické části i praktická cvičení. Cílem studie je ukázat rozmanitost, která v této oblasti panuje, uvést stávající relevantní přístupy do vzájemných souvislostí (a odhalit přitom i jejich myšlenkové pozadí) a nastínit, v čem může spočívat jejich př́inos pro studium literatury.

\section{Vývoj a typologie}

Ve svém mapování kořenů, z nichž vzešly postupy široce užívané v akademickém prostředí anglicky hovořících zemí, rozlišuje Paul Dawson čtyři typy, resp. okruhy historicky ukotvených přístupů, „institucionálních trajektorii““ (DAWSON 2005: 49), jejichž cílem je jak čtenářské a na něj navazující odborné porozumění literatuře, tak školení potenciálních spisovatelů. První z nich je více než na psaní založen na specifickém způsobu čtení literárních děl.

1) Z tohoto důvodu se místy přidržujeme termínu literární studia, který pro naše účely lze chápat jako synonymní k označení literární věda či literárněvědná bohemistika (a její studium). Ve všech případech je smyslem poznávání literatury, nikoli výchova potenciálních spisovatelů; historicky se oba tyto záměry mnohdy prolínají. 


\section{Čtení jako spisovatel, čtení zevnitř}

Koncept „čtení zevnitř “ či „čtení jako spisovatel“ (reading as a writer) je nejobecnějším ztělesněním předpokladu, že nejlepší cesta jak se naučit psát, je číst, přesněji číst jistým způsobem - se záměrem odhalit cesty jak zlepšit své vlastní psaní. Když Walter Bessant ve své eseji The Art of Fiction z roku 1884 vybízí ke kritickému čtení, míní tím právě odlišnost tohoto způsobu čtení od čtení pro potěšení, aniž by přitom pracoval s konkrétními analytickými nástroji. Po prvním čtení „pro příběh“ navrhuje číst znovu, pomalu a postupně, a klást si při tom otázku, jak autor novelu vystavěl (rozebrat a rekonstruovat, jaká je hlavní idea díla, postavy či prostor). Nezastupitelnost prvního „nekritického“ čtení zdůrazňuje také Dorothea Brandleová, která v roce 1934 již užívá přímo spojení čist jako spisovatel. Ve fázi kritického čtení doporučuje vyjít z otázky, co se čtenáři na knize líbí či nelíbí, zaměřit se na styl, kompozici, dialogy či hledisko (point of view) a sledovat, jak autor tyto aspekty řeší. Brandleová zároveň zdůrazňuje význam kritické revize vlastních textů, přičemž sám proces tvorby vnímá jako akt vycházející z podvědomí. Postup založený na sledování a nápodobě práce literárních mistrů se patrně ujal, nebở R. V. Cassill v knize Writing Fiction roku 1962 již varuje před mechanickými výpůjčkami literárních postupů od zavedených autorů. Smysl čtení pro potenciální spisovatele vidí v odhalování obecnějších principů společných kvalitní fikci.

V čem je čtení z pozice spisovatele odlišné od kritického porozumění literatuře, jak se vyučuje v hodinách literatury? Dle R. V. Cassilla se oba odlišují od čtení běžného - mimetického a iluzivního. Zatímco kritik (literární vědec) usiluje o porozumění hotovému dílu a umistuje je do kontextu (dobového, žánrového atd.), spisovatel se pokouší rekonstruovat proces komponování celku s ohledem na volby, které autor učinil; usiluje odvodit si proces utváření textu a porozumět mu. Rozhodnutí, jež autor činí, přitom sahají od volby tématu přes rozvržení syžetu až po výběr konkrétních slov.

Popsaný přístup se tedy zaměřuje na to, jak může (budoucí) spisovatel využít četbu zavedených autorů k rozvoji svých vlastních schopností. Označení číst jako spisovatel se zrodilo v tomto kontextu a zůstává funkční v odborné literatuře věnující se tvůrčímu psaní ve smyslu psaní literárního. Tam, kde je řeč o tvůrčím psaní jako o součásti literárních studií, se setkáme s pojmy „čtení zevnitř“ či „literatura zevnitř““ (IBID.: 49, 70).

Také čtení zevnitř je založeno na víře, že praktická zkušenost s psaním beletrie vede $\mathrm{k}$ lepšímu porozumění literatuře. Soustředěné úsilí formulaci výcho- 
disek a cílů věnoval ve 30. letech Norman F. Foerster, jehož jméno je spojeno s univerzitou v Iowě (Iowa Writers' Workshop). Specializaci v tvưrčím psaní zde předcházel obecněji zaměřený vzdělávací modul, v jehož rámci Foerster zamýšlel učinit kurzy tvưrčího psaní součástí vzdělávání moderního učence (man of letters). Jeho dalším záměrem bylo reformovat výuku literatury směrem od faktograficky zaměřeného studia vlivů $\mathrm{k}$ důrazu na praktickou kritiku. Role tvůrčího psaní je v procesu zvyšování jak všeobecné vzdělanosti, tak úrovně literatury podle Foerstera pomocná. Tvůrčí psaní poskytuje praktický vhled do fungování literatury; pisatel prochází týmiž kroky jako spisovatel (výběr slovního materiálu a jeho tvarování, revize textu) a díky tomu vidí celý proces a problémy s ním spojené zevnitř.

Tvưrčí psaní mělo na amerických univerzitách své místo po většinu 20. století, přičemž šlo obvykle o málo vyhraněný přístup směšující kompoziční cvičení s kreativním sebevyjádřením. Pokud jde o porozumění literatuře, počínaje 30 . léty a konče hluboko ve 2 . polovině 20 . století v kurzech tvưrčího psaní na amerických vysokých školách zakotvil formalistický př́istup k literárnímu dílu a jeho pojmový aparát. Etablování tvưrčího psaní jako součásti (byt̉ obvykle volitelné) vzdělávacích programů patrně dopomohl i vzestup nové kritiky ve 30. a 40. letech, vyloučen není ani zprostředkovaný vliv osoby T. S. Eliota, díky němuž $\mathrm{v}$ odborných kruzích vládl respekt $\mathrm{k}$ autoritě básníka a kritika $\mathrm{v}$ jedné osobě. Imaginativní psaní mělo být zrovnoprávněno jako legitimní obor studia. Dominujícím modelem výuky se přitom stal workshop - malá skupina vedená lektorem $\mathrm{k}$ pozornému čtení literárních textů. Jediným rozdílem lekce tvưrčího psaní oproti semináři vedenému s využitím close reading je vlastně to, že se zde čtou texty studentů. Obojí může zároveň evokovat poučenou, zaujatou debatu o poetických problémech v kruhu básníků.

Druhým Dawsonovým typem je literacy (lze přeložit nejspíše jako zdatnost, gramotnost). Obnáší prakticky koncipovaný výcvik v psaní - částečně slohový trénink, částečně psaní akademické. Cílem je zvládnutí produkce textových útvarů, s nimiž se absolvent setká v profesním kontextu, od administrativních po propagační. Tento typ psaní stojí mimo pole našeho zájmu. Zbývá tedy dvojice tvořivé sebevyjádření (creative self-expression) a řemeslo (craft).

Ani u jednoho $\mathrm{z}$ těchto přístupů se nutně nepracuje s konkrétními literárními texty, spíš s celkem studentovy (čtenářovy) zvnitřnělé představy o literatuře, jeho obecným žánrovým povědomím apod. Oba přistupy a cvičení z nich vycházející lze s úspěchem využít také v kurzech literárního psaní, kde se navzájem doplňují: na jedné straně stojí hledání a rozvíjení námětu, na straně druhé 
řemeslná stránka tvorby literárního textu. Využití těchto postupů pro vzdělávání ve smyslu porozumění literatuře, rozvíjení citlivosti k básnickému sdělení a poetické stránce reality spočívá obecně řečeno $\mathrm{v}$ přesunu důrazu na proces (místo na produkt) a v posílení fáze reflexe, kdy se realizuje uvědomění a v kontaktu s vlastní žitou realitou vzniká znalost.

Zatímco Dawson vychází ve své typologii ze zažité praxe, což mu umožňuje opírat se o vývoj jednotlivých typů, Dianne Donnellyová ve snaze etablovat creative writing studies jako akademickou disciplínu usiluje o abstraktnější, systematické členění různých podob výuky tvưrčího psaní. Za vzor si bere Meyera Howarda Abramse a jeho přehled estetických teorií, jak je popsán v knize Lampa a zrcadlo. Na místo uměleckých výtvorů ${ }^{2}$ však staví pedagogické př́istupy k tvorbě textu (DONNELLY 2009: 20) a mluví o čtyřech typech umělecké výměny či transakce (artistic transaction).

Mimetická teorie je tak založena na imitaci a spočívá v učení se nápodobou uznávaných spisovatelů. V jejím pozadí stojí předpoklad, že kopírováním textových strategií si je student osvojí a bude schopen porozumět výstavbě příběhu, praktikovat určitý styl, naučí se technice. Teorii výrazu (expressivist theory) lze postavit na roveň Dawsonova tvořivého sebevyjádření; bude o ní řeč níže. Svou pragmatickou teorii ztotožňuje Donnellyová s literárněvědnou teorií čtenářské odezvy (reader-response) a za její analogii v tvưrčím psaní považuje výuku zaměřenou na psaní textů s cílem dosáhnout zamýšleného účinku na čtenáře. V opozici k aspektu sebevyjádření je zde posílen komunikační rozměr textu, což se v pedagogické praxi projevuje například důrazem na naslouchání a tréninkem ve vzájemném poskytování zpětné vazby. Objektová teorie je odvozena od nové kritiky a jejího zaměření na dílo jako autonomní významovou jednotu. Příslušný pedagogický přístup klade důraz na pozorné, analytické čtení (v tomto ohledu se blíží Dawsonovu čtení zevnitř). Zmíněny jsou zde i různé příručky typu „jak na to“, které akcentují řemeslnou stránku psaní.

Ačkoli je samotná její typologie více spekulativní, Donnellyová je oproti Dawsonovi konkrétnější, pokud jde o popis vzdělávací vysokoškolské praxe, a alespoň u teorie výrazu (expressivist theory, psaní jako sebevyjádření) má její text vyšší informační hodnotu.

2) Ty mohou v Abramsově modelu odrážet svět, vyjadřovat vnitřní pocity autora, obracet se ke čtenáři či stát samy v centru pozornosti. 


\section{Psaní jako sebevyjádření}

Donnellyová vidí dva zdroje tohoto přístupu - pedagogické a umělecké. Pedagogické souvisí s obratem k žákovi, resp. studentovi, tedy s obratem od zaměření na předmět, kterým pedagogika prošla přibližně ve 20. letech 20. století. Důraz je nově kladen na individualitu a osobní rozvoj jedince. Výuka má vycházet $\mathrm{z}$ toho, co student zná a s čím se setkává v reálném světě své osobní zkušenosti, místo aby se odvozovala od struktury příslušného vědního oboru. V oblasti (literárního) psaní to také znamená povzbuzovat studenty, aby rozvíjeli své jedinečné vlohy. Úlohou učitele je vytvářet prostředí pro osvobození vnitřních tvořivých sil studentů.

Koncept tvưrčího génia zřetelně odkazuje k romantizujícímu pojetí tvorby, které je druhým, uměleckým zdrojem tohoto přistupu; ve 30. letech se nadto představa vnitřní tvořivé síly napájela také z psychoanalytické teorie nevědomí. Dochází zde k paradoxnímu spojení výlučné představy „božské síly“, talentu a imaginace s úsilím o maximální demokratizaci procesu tvorby, která nadále nemá být výsadou několika málo vyvolených jedinců. Jako pedagogické hnutí ztratil tento přistup sílu ve 40. a 50. letech, kdy ustoupil dưrazu na základní dovednosti a zřetelněji vymezený standard. Renesanci pak zažil v letech 60. a 70. v souvislosti s celkovým uvolněním, osvobozením od tradičních forem vzdělávání a rozmachem alternativních sebevzdělávacích kurzů.

V českém prostředí upozornil na souvislost konceptu sebevyjádření s romantickými představami o tvorbě Jiří Studený (STUDENÝ 2016: 45) s odkazem na Doormanovu knihu Romantický řád. V té najdeme možné vysvětlení, proč je koncept sebevyjádření dodnes živý nejen jako pedagogický přistup, ale také jako jeden ze stavebních kamenů teorie tvưrčího (literárního) psaní. S nástupem romantismu byla zproblematizována klasická pravidla tvorby založená na precizní znalosti tradiční poetiky. Namísto toho začala být žádoucí představivost, vzniká autorské umění a do centra pozornosti se dostává samotná osoba autora (DOORMAN 2008: 154-157). Ve světle dalšího vývoje literatury a zejména literární teorie je zřejmé, že tento koncept má pro teoretiky tvưrčího psaní, kteří jsou zpravidla také lektory a jako takoví usilují o rozvoj autorských schopností svých studentů, zvláštní hodnotu a je v jistém smyslu nenahraditelný.

Jak vysvětluje Donnellyová, v současnosti se vzdělávací systém opírá o jiné principy, ale tvưrčí psaní jako obor stále staví na principech sebevyjádření a klade si za cíl pomoci studentům najít jejich „pravé já“ a „vlastní, jedinečný hlas“ (DONNELLY 2009: 60). Pisatel se v tomto pojetí stává nejvyšší autoritou nejen 
při rozhodování o podobě vlastního díla, ale také v jeho hodnocení. Originalita je kladena nad imitaci a klíčovým se stává zážitek inspirace, který umožňuje odhalování „pravého já“ pod vrstvami sociálně podmíněného chápání sebe sama. Odvrácenou stranou tohoto pojetí je fakt, že věnuje minimální pozornost další práci se spontánně vzniklým prvopisem. Sugeruje studentovi, že psaní nevyžaduje zvláštní námahu, a důrazem na skutečnost, že se zdar díla odvíjí od přirozených vloh, jej do značné míry zbavuje zodpovědnosti nejen za vzniklý text, ale i za průběh vlastního studia. Jiří Studený (STUDENÝ 2016: 48n.) spatřuje meze tohoto přístupu v tom, že chápe psaní jako „vylévání“ hotového obsahu. Namísto toho rozvíjí představu psaní jako sebetvorby, aktualizace sebe sama. Nejen proces psaní či text, ale dokonce i pisatel je u něj chápán nesubstančně, procesuálně.

Pojem „sebevyjádření “ se objevil také v názvu práce autorů univerzity v Hradci Králové (DVOŘÁK a kol.: 2001). Zde shromážděné statě zřetelně odrážejí atmosféru porevolučního desetiletí; důraz na individualitu a autentičnost (autora i textu) rozvíjejí na pozadí předešlého uniformního, normami svázaného systému slohového vzdělávání. ${ }^{3}$ Rovnítko je kladeno mezi dobrý a vnitřně pravdivý text. Tvorbě takových textů má napomáhat seminář rozvíjení individuálního stylu, přičemž východiskem jsou de facto stále tradiční slohové útvary a postupy. Akcentovány jsou ty z nich, které umožňují výrazněji uplatnit autorskou subjektivitu (líčení, deník apod.). Cílem tvůrčího psaní má být znovuobjevení osobních dispozic, dávné upřímnosti a spontaneity, jakýsi návrat k ryzí podstatě, překryté nánosy neosobních konvencí. Důležitou součástí takto koncipovaného projektu rozvíjení individuálního stylu je dialog ve skupině. Sdílení studentských prací i četba literárních textů jsou inspirací pro další psaní. Nechybí ani varování před př́lišným zaměřením na „techniky“, které vede k pouhému mechanickému osvojování principů tvorby textu.

\section{Psaní jako řemeslo}

Příručky zaměřené na řemeslnou stránku psaní se začaly v hojné míře objevovat $\mathrm{v}$ Americe na sklonku 19. století. Jejich obliba souvisí s rozmachem časopisecké povídky a přetrvala prakticky po celé 20. století. Jak připomíná Dawson (DAWSON 2005: 60), tyto př́ručky měly dvojí cíl: podat instrukce pro pisatele

3) Produktem bezduchého naplňování konvencí přitom může být i obraznými pojmenováními nasycené líčení jarní př́rody, postrádající osobitost výrazu. 
a zároveň sloužit jako průvodce pro čtenáře. Zaměřovaly se na výstavbu př́iběhu, kompozici textu, podávaly vhled do techniky tvorby dialogů apod. Později se tento proud přirozeně propojil s formalistickou analýzou, což mu otevřelo dveře do univerzitního prostředí. Pedagogická atraktivita řemeslného př́istupu spočívá v tom, že se zaměřuje na ty stránky literárního psaní, které lze (po metodickém rozčlenění na uchopitelné elementy) dobře trénovat. Tvorba je zde vnímána jako řízená činnost, jako úsilí, nad nímž má autor vědomou kontrolu.

Vlastním územím řemeslného přístupu jsou učebnice pro spisovatele (u nás např. HRDLIČKA 2004, DOČEKALOVÁ 2006). Převažující návody technického rázu jsou zde prokládány jak cvičeními rozvíjejícími vnímavost vůči vlastním prožitkům i okolnímu světu (čerpání inspirace, hledání námětů, sebevyjádření), tak analýzou ukázek zavedených spisovatelů s pobídkou k nápodobě. Vedle tréninku v rozvíjení zápletky či tvorbě dialogu lze $\mathrm{k}$ řemeslnému př́istupu přiřadit například cvičení založená na změně vypravěčské perspektivy, žánrové variace a v širším pojetí také cvičení na principu stylistické nápodoby či parodie (vieweghovské „nápady laskavého čtenáře“). Teoretickou základnou je zde tradiční poetika a stylistika.

Příkladem užití v oblasti terciárního vzdělávání je učebnice Josefa Peterky Teorie literatury pro učitele. Jednotlivé výkladové kapitoly, v nichž se modernizovaná poetika hrabákovského střihu setkává s druhou generací českého strukturalismu, jsou hojně protkány příklady. Ty zahrnují Peterkovy vlastní zkusmé texty (metafory, typy vyprávění, variace) a také přiznaná cvičení uvedená formou zadání, tzv. „kreativně imitační etudy“ (PETERKA 2001: 131). Studenty vybízí, aby tvořili (a následně interpretovali) variace titulu známého díla, různými zpo̊soby za pomoci tropů a figur vyjádřili vyznání lásky nebo vytvářeli texty různých žánrů začínající týmž slovem. Cvičení mají za úkol studenty motivovat $\mathrm{k}$ aktivnímu zapojení do hodin literatury. Peterkovy modelové texty vedle toho disponují názorností, jaká je v reálných literárních dílech nedosažitelná, a slouží tedy jako učební materiál. Cílem je v obou případech porozumění teoretickým pojmům.

Na půdorysu literární teorie staví i Jiří Studený v knize Dramata jazyka. Teorie literatury a praxe tvưrčího psaní, respektuje však spíše její hloubkovou strukturu - v kapitole věnované poezii se např́klad věnuje rytmu a obraznosti jako konstitutivním rysům tohoto literárního druhu a zároveň jako součásti antropologické výbavy, nezávislé na pojmovém aparátu toho či onoho teoretického systému. Literatura, potažmo její zkoumání má pro něj smysl do té míry, do jaké si udržuje kontakt s lidským životem. Na vytváření kontaktu s texty 
a „rozehřivání " v nich akumulované sémantické energie je u autora zaměřena celá řada cvičení. Další spočívají v tvořivé práci s žánry, s fokalizací či v rozvijení dialogu.

\section{2. (Tvůrčí) psaní a studium literatury}

Jak je z předchozího patrné, spojení literárních studií a kurzů tvưrčího psaní jako jejich doplňku a podpory má $v$ anglicky hovořícím světě silnou tradici a v různých podobách existuje již několik desetiletí i u nás. Současné zahraniční vzdělávací programy, které využívají k dosahování specifických oborových cílů také různých forem psaní, vycházejí ze svébytných teoretických stanovisek a (snad i pro odlišení se od tradičních kurzů, v nichž je mnohdy petrifikován formalistický přístup $\mathrm{k}$ analýze literárního díla) volí také pro svou činnost jiné názvosloví. Proto se nejprve zastavme u samotného pojmu tvůrčí psaní. V jakém významu se jej v současné době užívá a jaké $\mathrm{z}$ toho plynou vzhledem $\mathrm{k}$ zaměření naší práce komplikace?

Na podzim roku 2014 uveřejnil časopis Host článek Jany Šrámkové Tvưrčí psaní za časů Berkové a dnes. Jeho jádrem je recenze knihy Alexandry Berkové $O$ psaní. Článek si vedle toho klade ambici být obecnější rekapitulací oboru tvưrčí psaní v České republice ${ }^{4}$ a lze jej považovat za reprezentativní příklad pohledu širší odborné veřejnosti na to, co je obsahem pojmu tvưrčí psaní a cílem vzdělávání v tomto oboru. ${ }^{5}$

Tvưrčí psaní vnímá Šrámková jednoznačně jako umělecký obor. Srovnáním s jinými uměleckými obory (např. výtvarnými) a jejich výukou se snaží vyrovnat s tradičními námitkami, že „psaní se přece nedá naučit“. Souhlasí s podstatnou podmínkou existence talentu a vyzdvihuje význam řemeslné průpravy, ale také soustavné reflexe všech fází vlastní činnosti ve skupině studentů pod vedením lektora. Takové soustavné vzdělávání v umění psát staví do protikladu ke krátkodobým kurzům tvůrčího psaní pro veřejnost, které se v době rozmachu seberozvojových aktivit pro dospělé těší značné pozornosti. Tvưrčí psaní jako součást (vysokoškolského) vzdělávání zmiňuje v jediné poznámce, když uvádí, že

4) Šrámková absolvovala tvưrčí psaní na Literární akademii Josefa Škvoreckého, mimo jiné i pod vedením Alexandry Berkové, a následně zde sama několik let vyučovala.

5) V povědomí veřejnosti laické se tvůrčí psaní pojí nejspíše se jménem Markéty Dočekalové, jejíž „učebnice tvưrčího psaní“ jsou dostupné v běžné distribuční síti. Dočekalová vymezuje tvůrčí psaní jako obor, který „dává vzniknout různým druhům literárních děl s cílem poskytnout je ke čtení veřejnosti“ (DOČEKALOVÁ 2006: 9). Do této definice tak vedle beletrie, resp. fabulované fikce spadá i psaní žurnalistické a také tvorba scénářů pro televizi a film. 
tvưrčí psaní se v českých zemích etablovalo mimo jiné „jako doplňkový předmět prakticky jakéhokoli studia“" (ŠRÁMKOVÁ 2014: 45). Pojem tvưrčí psaní je zde tedy do velké míry ztotožněn s psaním, které má estetické ambice a je výrazem autorského gesta tvořivé individuality.

V akademickém prostředí je základní publikací oboru Tvưrčí psaní. Malá učebnice technik tvưrčího psaní Zbyňka Fišera. Autor zde vychází z široce, tj. nikoli jen umělecky chápané kreativity jakožto schopnosti nacházet inovativní řešení problémových situací, at už v kontextu vzdělávacím, jazykovém (překladatelství), osobním (sebepoznání, terapie), vědeckém (akademické psaní) či firemním (management, reklama). Psaní umělecké, literární, je v tomto pojetí pouze jednou z podmnožin psaní tvůrčího. Může napomoci lepšímu chápání literárního díla, podstatnější je však rozvíjení osobního stylu autora a také jeho poznávacích schopností, estetické vnímavosti k okolnímu světu, empatie atd. Ve vyučování mají své místo různé imitační postupy, které umožňují poznat jak určité „zákonitosti“ autorské tvorby, tak lépe porozumět věcné i estetické informaci textu (FIŠER 2001: 21). Toto pojetí autor rozvinul v knize Tvưrčí psaní v literární výchově jako nástroj porozumění, o níž bude řeč níže.

$\mathrm{Na}$ Slovensku se tvưrčí psaní jako obor rozvíjelo v úzkém kontaktu s českým a také $s$ anglicky hovořícím prostředím zejména díky Vieře Eliašové. Ta se na Univerzitě Komenského v Bratislavě věnuje především odbornému jazykovému vzdělávání. Ve své publikaci Tvorivé písanie a možnosti jeho využitia $v$ edukačnom procese formuluje pro výuku vedenou s využitím metod tvůrčího psaní tři okruhy působnosti: jazykové vzdělávání, výuku literatury a rozvoj tvořivosti (jako součást badatelské práce i ve smyslu osobního rozvoje). Při formování literární kompetence postupy tvưrčího psaní umožňují recipientovi stát se spolutvưrcem textu, což aktivuje jak jeho literární vzdělání (povědomí o literárních žánrech apod.), tak individuální komplex zkušeností, jeho estetické cítění, intuici, představivost. To podle Eliašové vede $k$ pocitu osobní angažovanosti při práci s literárním textem, chápání literatury „zevnitř“ a k tvořivé reakci vlastní produktivní činností (ELIAŠOVÁ 2011: 81). Cvičení, která autorka nabízí a v nichž se pracuje s literárními texty, směřují spíše k využití literárních principů v procesu porozumění určitému tématu (např. metaforické uchopení sociologického fenoménu v podobě kuchařského receptu).

V jakém významu je pojem Creative Writing v současné době užíván v anglicky hovořících zemích a jaké má tvưrčí psaní místo na vyšších stupních vzdělávání? Relativně aktuální přehled o stavu oboru ve Velké Británii poskytuje materiál, který vznikl pod záštitou English Subject Centre při University of London 
(HOLLAND 2003). ${ }^{6}$ Konstatuje, že vzdělávací program zaměřený na tvůrčí psaní nabízejí desítky institucí (včetně programů magisterských a doktorských), a to jak v návaznosti na English Studies, tak jako součást umělecké profilace. Ačkoli oblast tvůrčího psaní zahrnuje také psaní akademické, profesní či žurnalistické, velká řada kurzů je zaměřena především na psaní literární, imaginativní - poezii, prózu a drama, přičemž je (jako externí vyučující) často vedou aktivní spisovatelé, popř. i odborníci z oblasti vydavatelského či zábavního průmyslu. Mnoho nových programů zakládaných odděleními anglického jazyka a literatury odráží potřebu a přání rozvíjet vedle čtenářských dovedností studentů také jejich schopnost psát. Někde je přitom (tvůrčí) psaní chápáno jako prostředek reflexe literárního díla - a terminologické nejasnosti trvají.

Pokud jde o lektorem řízenou textotvornou aktivitu studentů s cílem lépe porozumět literatuře, pojem tvůrčí psaní má, jak již bylo řečeno, v akademickém prostředí řadu alternativ. Ty se svým způsobem distancují od tradičně chápaného tvưrčího psaní a zároveň odrážejí osobitý přístup svých tvůrců, jejich odlišné teoretické i světonázorové zázemí.

\section{Textové intervence}

Rob Pope ve své knize, koncipované jako „kriticko-kreativní“ příručka (POPE 1995), volí označení textová intervence. V jednotlivých cvičeních vždy pracuje s výchozím textem, kterým je vedle textu uměleckého například i časopisecká reklamní dvoustránka. Právě u ní vyvozuje hlavní zásady svého přístupu k textu. Ten je podle něj nosičem ideologie, který vždy něco preferuje a něco zamlčuje. ${ }^{7}$ Samotný princip autorské tvorby (nevyhnutelná volba a konkrétní uspořádání jednotlivých prvků) je užit jako důkaz, že se textům nedá a nemá věřit. Pope zde zcela opomíjí postoj, jejž bychom s Coleridgem mohli nazvat dočasným odložením nedůvěry. Podobné „nekritické“ recipování je rovno indoktrinaci. Podle Popea je to vždy aktuální čtenář, kdo rozhoduje, které podněty nabízené textem rozvine. Studenty povzbuzuje k aktivnímu vyjednávání si své orientace namísto

6) Cílem řady Report Series, do níž tato publikace patří, je poskytovat kontextuální informace o stavu angličtiny jako vzdělávacího předmětu, o vztahu k národní vzdělávací politice a praktických a akademických zájmech, sdílených odpovídajícími pracovišti (srov. HOLLAND 2003: 1).

7) V lyrickém textu jsou to zájmena, která privilegují, marginalizují či vylučují různé pozice. U narativních textů volba zobrazených událostí a zahrnutých okolností zastírá fakt, že se příběh mohl stát jinak - vedle toho, co je přítomno, vždy něco chybí nebo je přinejmenším zpochybnitelné. 
přijímání pozice nabídnuté textem se zdůrazněním, že je to vždy čtenář, kdo má finální kontrolu (IBID.: 52).

Vedle tohoto zdůrazňování „silové“ či „mocenské“ povahy textů je dalším výrazným rysem Popeova přistupu radikální chápání textu jako otevřené sítě významů; je to právě tato otevřenost, která umožňuje do textu zasahovat a přetvářet jej, aniž by se vytratila spojitost $s$ výchozím zněním. Jednotlivá cvičení vybízejí čtenáře a pisatele ke změně těžiště (přesunu pozornosti $k$ „tomu upozaděnému“), změně žánru, tvorbě parafráze, adaptace, parodie či koláže. Hojně se objevují také úkoly jako socialistická či feministická odpověd' (response) určitému kanonickému textu, stejně jako tvorba paralelních, alternativních či proti-textů. ${ }^{8}$

Stejně jako u jednotlivých tematických okruhů navrhuje ve výuce nejprve přečíst výchozí text (typicky ukázku z literárního díla), následně zařadit cvičení a na samý závěr odpovídající pasáže literární teorie, tak i v jeho knize je „relevantní a užitečná (usable) teorie“ zařazena na konci. Bachtina, Derridu, Foucaulta nebo Macheraye využívá Pope jako oporu pro své soudy a zároveň se vůči poststrukturalistické teorii vymezuje ryze praktickým užitím klíčových postulátů jako výukových metod. Celkové pojetí je ukotveno v realitě současné Británie jako multikulturní země zatížené dědictvím velkého jazyka. Pope vnímá individualitu jako průsečík mnoha různých sil; zdůrazňuje kulturní odlišnosti, ale také tvořivé gesto jednotlivce. Koncept hlasu (voice) se zde prolíná s rezidui romantické představy autora-tvưrce. Autor ponechává jednotlivci dokonce i výsadní právo hodnotit, která „verze Hamletova monologu“ - míněno Shakespearova nebo studentova - je lepší.

\section{Transformativní psaní}

Pod označením Transformative Writing se skrývá vysokoškolský vzdělávací program „aktivního čtení“, jehož cílem je čtenářská autonomie. Autoři Ben Knights a Chris Thurgar-Dawson zde reagují na aktuální situaci, kdy narůstá počet studentů a výrazněji se diverzifikují jejich potřeby. $\mathrm{K}$ rozrůznění a rozplývání ustálených hranic dochází také na straně kurikula stejně jako kánonu; zpochybněno je v př́ípadě literatury i samotné médium. Realita kulturní

8) Obdobná označení (konkrétně paralelní a kontrastní text) pro tvořivou nápodobu textového vzoru užívá Jiří Studený v metodicky precizně rozfázované dvojici cvičení (STUDENÝ 2016: 53-64). Zatímco Pope se převážně drží ideově tematické roviny výchozích textů, Studený vidí jejich sémantické i tvarové danosti jako východisko pro inovativní autorské zásahy a v celé aktivitě akcentuje moment nepřímé, nedirektivní analýzy původního díla. 
rozmanitosti má být v jejich pojetí, které je striktně vedeno didaktickým záměrem, pobídkou ke snaze o vzájemné obohacení a porozumění, nikoli jen ospravedlněním relativizace. Neopouštějí ani tradiční představu umělecké hodnoty - pro počáteční fáze vzdělávacího procesu navrhují volit čtenářsky přístupné a do jisté míry i atraktivní texty, aniž by tvrdili, že „studium Keatse lze nahradit tvorbou limerickü“ (KNIGHTS, THURGAR-DAWSON 2006: 158). V podobném duchu proklamují i nezpochybnitelné místo a význam tradičních forem studentského psaní ( $v$ anglosaském prostředí je to především esej) i tradičních forem vzdělávání, jako je přednáška a seminář.

Odlišnost svého pojetí psaní od psaní tvůrčího vnímají v práci se zdrojovým textem, k němuž se $\mathrm{v}$ průběhu aktivity důsledně vrací pozornost. Psaní má být nejen poznáváním literatury zevnitř (viz výše), ale také součástí procesu utváření znalostí; znalost je zde chápána jako nepřenosná v „hotové“ podobě. Důležitým aspektem je také „zážitek potěšení v psaných slovech“, aniž by to mělo vést k nekritickému přitakání „narcistické kultuře sebevyjádření“ (IBID.: 160).

Navrhovaná textotvorná cvičení jsou velmi různorodá (změna hlediska či žánru, tvorba dialogu mezi vedlejšími postavami, vepsání veršů do básně) a pokrývají prakticky kompletní typologii, jak o ní bude řeč dále. Vedle samotného zadání je důraz kladen na vytvoření bezpečného prostoru pro učení a na „ekosystém“ (IBID.: 159) tvořený textem a skupinou studentů. Ve vztahu k textům se zde prosazuje spolu-psaní (co-writing), psaní s textem (alongside the text). To přispívá $\mathrm{k}$ celkovému dojmu, že přání porozumět textu je pro autory silnější než potřeba s ním polemizovat.

\section{Literární experiment}

Ze zcela jiné strany přichází Edward Balcerzan s návrhem experimentu při interpretaci literárního díla. Jeho záměr je ryze odborný, nikoli pedagogický, přesto navrhované postupy (jak ukážeme dále) lze velmi dobře využít také ve vyučování. Balcerzan se opírá o strukturalistické myšlenkové zázemí, přičemž východiskem je mu zde spíše strukturalismus lingvistický; výslovně zmiňuje Chomského Syntaktické struktury. Experiment chápe jako intelektuální operaci, při které se hotové literární dílo jistým způsobem deformuje, aby se potvrdila nebo vyvrátila určitá interpretační teze (BALCERZAN 1972: 491). Domnívá se, že $\mathrm{v}$ latentní podobě je tato operace př́tomná v řadě kritických výpovědí o literárním díle - lze si představit například změnu emocionálního zabarvení či 
proměnu konotací při zkusmém nahrazení určitého výrazu např. v básni jeho synonymem. Podobné operace vycházejí z přesvědčení, že dílo má integrální a systémovou povahu, tvoří významovou celistvost. Díky tomu, že systém označujících nějakým zpo̊sobem vychýlíme z rovnováhy, můžeme lépe odhalit jeho individuální konstitutivní rysy. Nejde o tvorbu variací či alternativ, ale naopak o potvrzení nenahraditelnosti prvků v jedinečném významovém celku.

\section{Tvořivá cvičení Zdeňka Kožmína}

Z velmi podobných - tedy strukturalistických - teoretických pozic vychází Zdeněk Kožmín. Navrhuje i obdobné zásahy do textu (dokončení posledních dvou veršů, cvičná náhrada jednoho vyjádření jiným), a to v kapitole Práce s básní ve škole, která vznikla v roce 1986 u příležitosti opožděného vydání skript Interpretace básni. ${ }^{9}$ Jde o tvořivé zásahy do uměleckého díla, jejichž cílem je lepší porozumění původnímu textu. Zatímco tedy Balcerzanův příspěvek zůstává v teoretické rovině a klade otázky po metodologii interpretace jako odborné práce, Kožmín se pohybuje v kontextu vzdělávacím - interpretace básnického textu se zde stává součástí výukového dialogu, který je ovšem zároveň součástí komunikační intence díla.

Pro interpretaci textu „je třeba vytvořit atmosféru a reálnou situaci skutečného dialogu" (KOŽMíN 1992: 33), přičemž svého druhu interpretací je již zvuková realizace. Literární text je ve výuce vždy především textem čteným či slyšeným v prostředí školní třídy nebo seminární skupiny, tedy v přirozeném i když pedagogicky řízeném - společenství recipientů. Hlasité čtení či přednes (a na druhé straně poslech) místo tichého čtení je zejména u poezie faktorem, jehož význam pro porozumění a interpretaci lze jen stěží docenit. S odkazem na Patočku dále Kožmín vyzdvihuje antropologickou vrstvu interpretace (IBID.: 35), kdy zaujmeme pozici tázání, vystavíme se významové nejednoznačnosti uměleckého textu.

Má-li být interpretace individuálním výkonem, student potřebuje získat prostor pro vyjádření a také pro vlastní prožitek. Zde mohou sehrát klíčovou roli právě textotvorná cvičení inspirovaná literárním dílem, která v takové situaci prodlužují a zviditelňují akt recepce a umožňují sdílení významů. Proces

9) Rukopis připraven na počátku 70. let, 1. vydání Praha: Státní pedagogické nakladatelství, 1986. 
interpretace uměleckého textu se stává součástí pedagogické komunikace a tvořivé postupy zde mají své místo jako médium interpretačního dialogu.

Postupy, které Kožmín systematicky rozvíjel, se zrodily z pedagogického přístupu propojujícího v maximální míře vzdělávání jazykové, literární a slohové. Mnohočetné průniky recepce a produkce textu, stanou-li se běžnou součástí vyučovací hodiny či semináře, umožňují studentům nejen chápat psaní jako nástroj přemýšlení, ale také si osvojit pravidla tvorby textů různého druhu. Nejde přitom $v$ žádném případě o pouhou konverzaci, důraz je kladen na utváření znalostí.

Na tento aspekt Kožmínova př́istupu přímo navazuje Zbyněk Fišer v kolektivní monografii Tvưrčí psaní v literární výchově jako nástroj poznávání. ${ }^{10}$ Textotvorná cvičení v literárním vzdělávání nemají směřovat k rozvoji produkční literární kompetence. Operace s texty a vlastní „literární“ pokusy jsou jednou z cest, jak mohou studenti porozumět literárním textům, případně sobě samým (FIŠER a kol. 2012: 15n.). Obor tvưrčí psaní je zde přitom chápán jako součást teorie jednání - podstatným rysem tvorby textu je ohled na přijemce a také zodpovědnost za vlastní výtvor. K akcentování etické stránky vede autory pocit devalvace psaného slova a jeho zneužívání pro manipulativní či přímo mocenské záměry. Poznávací rozměr je pak vlastní i literatuře jako takové - esteticky tvarovaná sdělení zachycují rozmanité aspekty lidského pobývání ve světě a umožňují také nahlédnout do uvažování jiného, „cizího“.

Smyslem textotvorných cvičení je nasměrovat přirozenou tvořivost studenta a začlenit ji mezi jeho pracovní metody (IBID.: 10). Zadání shromážděná v knize jsou z podstaty kolektivní práce velmi různorodá, což nám dává př́iležitost je na tomto místě rozčlenit do několika okruhů. Pro systematický pohled zde poslouží Schmidtův model literárního komunikačního jednání (NÜNNING 2006: 187n.). Metody psaní, využívané pro lepší porozumění literatuře, lze rozlišit podle toho, na kterou z rolí literárního jednání (produkce, zprostředkování, recepce a zpracování) se zaměřují a s jakou fází komunikačního procesu jsou spojené.

Logickým východiskem je situace, kdy se student přímo v semináři setkává s literárním textem. Na fázi recepce se zaměřují cvičení, která vybízejí k formulování vlastního čtenářského zážitku formou volných či řízených asociací - souvislý „automatický“ text, asociace podle pěti smyslů apod. Tyto asociativ-

10) Kniha je určena zejména pro střední školy, proto se zde s ohledem na srozumitelnost hovoří o literární výchově, řada předložených cvičení však vzešla z vysokoškolského prostředí, kde byla také ověřena. - Na Kožmína Fišer odkazuje v již zmíněné publikaci Tvưrčí psaní, a to především na Kožmínův Tvořivý sloh. Zde najdeme také cvičení inspirovaná uměleckými texty, jde ale - jak název napovídá - spíše o cvičení slohová, jejichž cílem je rozvíjení vyjadřovacích a vůbec komunikačních schopností pisatele. 
ní techniky umožňují zachytit zážitek v jeho bezprostřednosti. Od představy $\mathrm{k}$ vyjádření, ale stále ještě formou imaginativního kódu, směřují cvičení, v nichž mají studenti za úkol vytvořit ilustraci nebo odpovědět na modelové otázky, cílící k postižení určitého sémantického rysu díla, např. jakou má báseň barvu.

$\mathrm{V}$ dalším okruhu cvičení jsou formou brainwritingu, akrostichu, mentální mapy nebo clusteru sumarizovány a v případě mentální mapy i logicky uspořádány jednotlivé informace. Zde se ocitáme ve fázi zpracování: získané poznatky lze následně přetavit do souvislého odborného textu (kupř. interpretační eseje), nebo literární text poslouží jako podklad pro vytvoření reklamy, traileru apod. tím se dostáváme na hranici komunikačního systému literatury.

Jinou možností je vstoupit dovnitř do textu a/nebo do fikčního světa interpretovaného literárního díla. Studenti mohou být vyzváni k vytvoření vsuvky nebo variace (a vzít $v$ potaz i jazyk a styl díla), popřípadě $\mathrm{k}$ zaplnění či extenzi fikčního světa, například zadáním napsat fiktivní dialog zúčastněných postav, dopis apod. Další možností jsou žánrové transpozice či variace ustálených výrazových forem. Výchozí text pak funguje jako př́iklad a vytvořený text je jeho paralelou. Student se v tomto případě věnuje produkci (kvazi)literárního textu.

Do hry zde vstupuje literatura jako soubor žánrů a kódů, z nichž si student vybírá. V tomto smyslu se tedy ocitá ve stejné situaci jako samotný autor, který je také nutně ovlivněn dosavadním vývojem literárního systému a aktuální estetickou normou. $\mathrm{V}$ přiznané podobě vstupují tyto vlivy do literárního díla jako intertextuální prvky, případně je celý text koncipován jako koláž. Jinou možností jak nechat studenta zakusit, co to znamená být autorem, nabízejí cvičení či „malé projekty“ založené na zaznamenávání událostí vlastního života a postupném přetváření těchto záznamů do literární, tedy stylizované podoby.

\section{Závěrem}

Společným rámcem všech uvedených přístupů je výuka literatury a s ní spojená komunikační situace, v níž se studenti s vyučujícím společně ocitají před literárním textem. Pro lepší porozumění tomuto textu, potažmo literatuře jako takové, studenti pod vedením vyučujícího tvoří texty vlastní. Ty pak - stejně jako text výchozí - navzájem sdílejí a v reflexi se dobírají obecněji platných poznatků. Abychom získali komplexní představu o všech spolupo̊sobících faktorech, je třeba si uvědomit, že popisované procesy se odehrávají jednak v kontextu literárního systému (známé žánry, klasické příběhy, postavy; estetické 
normy jednotlivých vývojových období), dále v kontextu aktuální žité skutečnosti čtenářů-studentů a v neposlední řadě ve vztahu mezi studenty navzájem a mezi studenty a vyučujícím, který průběh komunikace koriguje. Literární systém vstupuje do tohoto procesu jednak explicitně (v podobě ukázek, s nimiž se pracuje), jednak implicitně, a to do té míry, nakolik jej studenti znají - zde hraje klíčovou roli evokace, zpřítomnění poznatků. Rízená textotvorná činnost studenta přitom vždy osciluje mezi literárním systémem, který je předmětem studia, a mezi vlastní aktuálně žitou skutečností, z níž pisatel čerpá a k níž se obrací. Celý proces lze také chápat jako intertextuální.

Literární teorie $\mathrm{v}$ uplynulých desetiletích postupně přesouvala své těžiště od zájmu o autora (jeho biografické či psychologické pozadí) k důrazu na strukturu literárního díla a později na jeho recepci. V současném rozmachu adaptačních studií můžeme spatřovat další logický krok v intenci tohoto procesu, tedy pomyslného pohybu teoretické reflexe na ose autor - dílo - čtenář. Domníváme se, že podobně logickým krokem je zaměření pozornosti na práci s literárním textem ve vzdělávání, kde dochází (vrátíme-li se ještě jednou ke Schmidtovu modelu) ke zprostředkování. V roli zprostředkovatele je úkolem vyučujícího cíleně intervenovat do procesu recepce literárního díla čtenářem-studentem, a to v celém rozsahu recepce, tedy od způsobu předložení díla a výběru kontextuálních informací11 ${ }^{11}$ o reflexi, která směřuje $\mathrm{k}$ analýze a interpretaci.

Postupy využívající různých forem psaní mohou být jednou z forem této intervence, a to formou v mnoha ohledech adekvátnější než jiné, tradiční podoby výuky, které někdy staví mezi čtenáře a dílo spíše jakousi překážku. V klasických literárněhistorických seminářích se nabízejí především cvičení založená na práci s konkrétním literárním textem, v předmětech typu Tvưrčí psaní pro bohemisty či Úvod do studia literatury lze pracovat s širšími celky a zkoumat povahu „literárnosti“ jako takové.

Ačkoli je zde užívání pojmu tvưrčí psaní z mnoha důvodů, které jsme nastínili výše, málo výstižné a možná až problematické, důraz na tvořivost, kterou toto označení implikuje, je i ve vzdělávacím kontextu zcela na místě. Tvořivost je cenným protipólem pojmového diskursu a může jej vhodně doplňovat. Schopnost proniknout do podstaty imaginativních postupů, na nichž je řada tvořivých cvičení založena, je nezbytným předpokladem porozumění literatuře jako estetické výrazové soustavě. Tvůrčí psaní se v literární výchově na všech stupních škol může stát - a někde už se stalo - jedním z prostředků rozvíjení

11) Součástí předložení díla je v univerzitním prostředí už samotný sylabus předmětu, zařazení díla do seznamu četby apod. Moment předložení díla má tedy také institucionální rozměr, v jehož rámci se vyučující pohybuje. 
literární kompetence jakožto „schopnosti vytvářet a chápat poetické struktury“ (NÜNNING 2006: 393), přičemž v edukačním procesu jde především o rozvíjení recepční, nikoli produkční stránky této kompetence.

Základní rozvržení komunikační situace v literárním semináři zároveň kopíruje několik velmi bytostných rysů literárního světa. Sdílení mluveného slova a jeho poslech se napájí na orální tradici, v níž slovesnost existovala dlouho před vynálezem písma. Ze stejného důvodu je nezanedbatelné také spolubytí čtenář̉ a posluchačů v reálném čase, jejich osobní přítomnost. Ve vztahu vyučujícího a studentů se zrcadlí vztah mistra a adepta, založený na společné úctě k předávaným poznatkům, o něž tu jde především. S pronikáním do světa literatury jsme vždy také uváděni do jisté kultury (byt’ s vědomím jejich plurality) v jednotícím rámci tradičního jazykového společenství.

\section{LITERATURA}

BALCERZAN, Edward

1972 „Experiment pri interpretácii literárního diela“, in Slovo, význam, dielo.

Antológia pol'skej literárnej vedy (Bratislava: Slovenský spisovatel')

DAWSON, Paul

2005 Creative Writing and the New Humanities (London and New York: Routledge)

DOČEKALOVÁ, Markéta

2006 Tvưrči psaní pro každého (Praha: Grada)

DONNELLY, Dianne J.

2009 Establishing Creative Writing Studies as an Academic Discipline. Disertační práce (University of South Florida). Dostupné z http://scholarcommons.usf.edu/etd/ 3809 [12. 10. 2017]

DOORMAN, Maarten

2008 Romantický rád (Praha: Prostor)

DVOŘÁK, Jan a kol.

2001 Psaní jako sebevyjádření (Hradec Králové: Gaudeamus)

ELIAŠOVÁ, Viera

2011 Tvorivé písanie a možnosti jeho využitia v edukačnom procese (Bratislava: Univerzita Komenského)

FIŠER, Zbyněk

2001 Tvưrči psaní. Malá učebnice technik tvưrčího psaní (Brno: Paido) 
FIŠER, Zbyněk a kol.

2012 Tvưrčí psaní v literární výchově jako nástroj poznávání (Brno: Masarykova univerzita)

HOLLAND, Siobhán

2003 Creative Writing: A Good Practice Guide (London: English Subject Centre, Royal Holloway, University of London). Dostupné z http://english.heacademy.ac.uk/wp-content/uploads/2015/10/cwguide.pdf [26. 5. 2016]

HRDLIČKA, František 2004 Průvodce po literárním řemesle. Základy tvưrčího psaní (Praha: Votobia)

KNIGHTS, Ben - THURGAR-DAWSON, Chris

2006 Active Reading. Transformative Writing in Literary Studies (London: Continuum)

KOŽMíN, Zdeněk

1992 „Interpretace jako dialog“, Revue Filozofické fakulty Brno, 3. roč., č. 1, s. 33-36

1995 Tvořivý sloh. Malé traktáty a malé scénáře (Praha: Victoria Publishing)

1997 Interpretace básní (Brno: Masarykova univerzita)

NÜNNING, Ansgar (ed.)

2006 Lexikon teorie literatury a kultury (Brno: Host)

PETERKA, Josef

2001 Teorie literatury pro učitele (Praha: Univerzita Karlova)

POPE, Rob

1995 Textual Intervention. Critical and Creative Strategies for Literary Studies (London and New York: Routledge)

STUDENÝ, Jiří

2010 Dramata jazyka. Teorie literatury a praxe tvưrčího psaní (Červený Kostelec: Pavel Mervart)

2016 Povytažený dráp. Eseje o tvưrčím psaní (Červený Kostelec: Pavel Mervart)

ŠRÁMKOVÁ, Jana

2014 „Tvưrčí psaní za časů Berkové a dnes“, Host 30, č. 10, s. 45-49

Mgr. Jitka Cholastová, cholastova@mail.muni.cz, Ústav české literatury a knihovnictví, Filozofická fakulta, Masarykova univerzita, Brno, Česká republika / Department of Czech Literature and Library Studies, Faculty of Arts, Masaryk University, Brno, Czech Republic

Toto dílo Ize užít $v$ souladu s licenčními podmínkami Creative Commons BY-NC-ND 4.0 International (https://creativecommons.org/licenses/by-nc-nd/4.0/legalcode). Uvedené se nevztahuje na díla či prvky (např. obrazovou či fotografickou dokumentaci), které jsou v díle užity na základě smluvní licence nebo výjimky či omezení příslušných práv. 